\title{
Validation of the Polish version of P-QoL questionnaire
}

\author{
Jakub Rzepka' ${ }^{1,2}$, Kamil Zalewski ${ }^{1,}{ }^{\text {, Artur Stefanowicz }}{ }^{3}$, Vik Khullar ${ }^{4}$, Steven Swift ${ }^{5}$, \\ G Alessandro Digesu ${ }^{4}$ \\ ${ }^{1}$ Department of Gynecologic Oncology, Hollycross Cancer Center, Kielce, Poland \\ ${ }^{2}$ Center for Postgraduate Education, Department of Obstetrics and Gynaecology, Bielanski Hospital, Warsaw, Poland \\ ${ }^{3}$ Chair And Department Of Obstetrics, Gynaecology and Gynaecologic Oncology, II ${ }^{\text {nd }}$ Faculty of Medicine, \\ Warsaw Medical University, Poland \\ ${ }^{4}$ Department of Urogynaecology, St Mary's Hospital, Imperial College NHS Trust, London, United Kingdom \\ ${ }^{5}$ Department of Obstetrics and Gynecology, Medical University of South Carolina, Charleston, USA
}

\begin{abstract}
Objective: Pelvic organ prolapse (POP) is a common morbidity that affects many women and significantly decreases quality of life. The severity and the impact of the prolapse on the quality of life are important parameters in the management and follow-up of affected patients. The aim of this validation study was to validate the Polish version of the Prolapse Quality of Life questionnaire (P-QoL).

Material and methods: The P-QOL questionnaire was translated into Polish and administered to women recruited from two gynecological outpatient clinics $(n=231)$. Both symptomatic and asymptomatic women were included in the study and examined in supine position using the Pelvic Organ Prolapse Quantification System (POP-Q). The validity was assessed by comparing symptom scores and quality-of-life scores between symptomatic and asymptomatic women.

Results: A total number of 154 symptomatic and 77 asymptomatic women were included. There was a strong correlation between severity of the disease based on physical findings (POP-Q scale) and the P-QoL scores in main prolapse quality-of-life domains. The overall scores for each life domain were significantly different between symptomatic and asymptomatic women $(p<0.001)$. All the questions regarding symptoms showed significant differences $(p<0.001)$ between both groups.

Conclusions: The Polish version of P-QoL is a valid, reliable, and easily comprehensible instrument to assess quality of life and symptoms in Polish-speaking women suffering from urogenital prolapse.
\end{abstract}

Key words: pelvic organ prolapse, quality of life, P-QoL, prolapse symptoms, validation study

\section{INTRODUCTION}

Pelvic organ prolapse (POP) is a common female disorder. The number of the affected women is expected to increase by $45 \%$ in the next 30 years as a result of a steadily growing longevity among women aged 50 years and more [1]. POP carries very little morbidity but has a great influence on patient quality of life. Thus, evaluation of the impact of the occurrence and severity of the condition is best-done using disease-specific quality of life tools. The Prolapse Quality of Life questionnaire (P-QoL) is a disease-specific quality of life questionnaire that proved to be a valid and reliable instrument of assessing symptom severity, quality of life, and treatment outcomes in women with POP [2].
In terms of worldwide implementation, the crucial aspect of questionnaires assessing life quality is their applicability in many different settings and countries. This requires their translation into several languages and validation. To date, the P-QoL questionnaire has been validated for Italian-speaking patients and published by Digesu et al., in 2003. Then, it was translated into several languages including English, German, Dutch, Slovakian, Persian, Portuguese, Thai, Japanese, and Turkish [2-9].

\section{OBJECTIVES}

The aim of our study was to translate and validate the P-QoL questionnaire into the Polish language. 


\section{MATERIAL AND METHODS}

The P-QoL questionnaire was translated and validated in several languages [2-9]. The steps of translation and validation were similar in each language. Therefore, we decided to perform the Polish translation and validation in the same manner.

Local Ethics Committee approved of the study. Two independent English-Polish translators, unfamiliar with P-QoL, created the Polish version of the questionnaire. All linguistic and merit-related controversies were resolved with physicians fluent in English (J.R. and K.Z.) and the final version of the Polish questionnaire was accepted. The questionnaire was then back translated into English to prevent any misunderstandings in the Polish version. Both, the original English questionnaire and its Polish equivalent consisted of 38 questions, with 20 questions representing nine quality of life domains (general health perception, prolapse impact, role and physical limitations, social limitations, personal relationships, emotional problems, sleep/energy disturbances and symptoms severity) and 18 questions about prolapse symptoms. The responses ranged from „none/not at all" through "slightly/a little" and "moderately" to „a lot". A four-point scoring system for each item was used for severity measurement of urogenital prolapse symptoms. The questionnaire does not form the combined score. If a woman has only one domain affected and another woman has all domains affected, both will be considered symptomatic but in different aspects of life quality.

The questionnaire was printed in a large font ( 16 point) and in a horizontal format in order to improve readability, especially for elderly women.

\section{Study design}

Respondents were recruited among consecutive women referred to the urogynecological outpatient clinic at the University Teaching Hospital in Warsaw. An informed consent was obtained from each subject.
The P-QoL questionnaire was distributed among women who agreed to participate in the study. The responses were reviewed and any unanswered questions were completed. Subsequently, all the women were examined in the supine position using the Pelvic Organ Prolapse Quantification System (POP-Q) [10]. Baseline demographic and clinical data were collected.

\section{Statistical analysis}

Mann-Whitney $\mathrm{U}$ test was used to compare scores between symptomatic and asymptomatic women. Spearman's correlation was used to evaluate the relationship between P-QoL domain scores and vaginal examination findings in the symptomatic group. Internal consistency was tested using Cronbach's alpha coefficient. Alpha values of $>0.8$ were considered as excellent [11]. All tests were 2-tailed and type-1 error was set at alpha $<0.05$. Sample size was calculated for power of $90 \%$ and 2:1 allocation of patients.

\section{RESULTS}

A total of 260 consecutive women were asked to participate in the study. Fifteen women declined, and 14 women (aged 24-30) with asymptomatic prolapse were rejected due to inability to match the groups for age. Thus, a total of 231 women were enrolled. One hundred and fifty-four women $(66.7 \%)$ presented with complaints of pelvic organ prolapse and 61 (33.6\%) had other GYN complaints and were considered asymptomatic for pelvic organ prolapse at the initial work-up. Basic demographics and the grade of uterovaginal prolapse are shown in Table 1. Both groups (symptomatic and asymptomatic) were matched for age. Mean age was 65.6 years (range 33-91) for symptomatic and 64.9 years (range $30-85$ ) for asymptomatic women $(p=0.8)$. There were no differences in the weight between the two groups, mean weight was $70.57 \mathrm{~kg}$ (range 53-115) for symptomatic and $69.86 \mathrm{~kg}$ (range 49-97) for asymptomatic women $(p=0.7)$. There was an equal number of

Table 1. Basic characteristic of symptomatic and asymptomatic women with pelvic organ prolapse

\begin{tabular}{|l|c|c|c|}
\hline & Symptomatic $(\mathbf{n}=\mathbf{1 5 4})$ & Asymptomatic $(\mathbf{n}=\mathbf{7 7})$ & P value \\
\hline Age (mean, years) & 65.6 & 64,9 & 0.8 \\
\hline Weight $[\mathrm{kg}]$ & 70.57 & 69.86 & 0.7 \\
\hline Parity (mean) & 1.9 & 2.6 & 0.6 \\
\hline POP-Q findings & & & \\
\hline Grade 0 & $0(0 \%)$ & $43(55.8 \%)$ & $<0.001$ \\
\hline Grade 1 & $33(21.5 \%)$ & $27(35.1 \%)$ & 0.01 \\
\hline Grade 2 & $47(30.5 \%)$ & $4(5.2 \%)$ & $<0.001$ \\
\hline Grade 3 & $64(41.5 \%)$ & $3(3.9 \%)$ & $<0.001$ \\
\hline Grade 4 & $10(6.5 \%)$ & $0(0 \%)$ & $<0.001$ \\
\hline
\end{tabular}


Table 2. Comparison of mean quality-of-life domain scores in symptomatic and asymptomatic women (SD values are provided in brackets. U Mann-Whitney test)

\begin{tabular}{|l|c|c|c|}
\hline Prolapse quality of life domains & Symptomatic & Asymptomatic & P value \\
\hline General health perception & $46.11(20.33)$ & $19.67(25.17)$ & $<0.001$ \\
\hline Prolapse impact & $74.38(29.42)$ & $20.55(32.06)$ \\
\hline Role limitations & $53.17(39.04)$ & $9.62(25.92)$ & $<0.001$ \\
\hline Physical limitations & $53.67(38.92)$ & $10.71(25.85)$ & $<0.001$ \\
\hline Social limitations & $33.92(34.28)$ & $5.87(18.41)$ & $<0.001$ \\
\hline Personal relationships & $40.69(46.82)$ & $4.76(17.06)$ & $<0.001$ \\
\hline Emotions & $43.40(35.01)$ & $6.03(15.01)$ & $<0.001$ \\
\hline Sleep/Energy & $40.12(31.89)$ & $9.39(22.84)$ & $<.001$ \\
\hline Severity measures & $41.88(29.06)$ & $4.88(10.37)$ & $<.001$
\end{tabular}

Table 3. Internal consistency (Cronbach alpha coefficient) for prolapse quality of life domains

\begin{tabular}{|l|c|}
\hline Prolapse quality of life domains & Cronbach Alpha \\
\hline Role limitations & 0.949 \\
\hline Physical limitations & 0.931 \\
\hline Social limitations & 0.930 \\
\hline Personal relationships & 0.944 \\
\hline Emotions & 0.932 \\
\hline Sleep/Energy & 0.933 \\
\hline Severity measures & 0.932 \\
\hline
\end{tabular}

Table 4. Correlation between prolapse quality of life domains and vaginal examination findings (POP-Q stage) in symptomatic women

\begin{tabular}{|l|c|c|}
\hline Prolapse quality of life domains & Spearman's rho coefficient & P value \\
\hline General health perceptions & 0.448 & $<0.001$ \\
\hline Prolapse impact & 0.647 & $<0.001$ \\
\hline Role limitations & 0.578 & $<0.001$ \\
\hline Physical limitations & 0.566 & $<0.001$ \\
\hline Social limitations & 0.506 & $<0.001$ \\
\hline Personal relationships & 0.522 & $<0.001$ \\
\hline Emotions & 0.593 & $<0.001$ \\
\hline Sleep/Energy & 0.564 & $<0.001$ \\
\hline Severity measures & 0.694 & $<0.001$ \\
\hline
\end{tabular}

vaginal deliveries in both, asymptomatic and symptomatic women ( 2.6 and 1.9 , respectively; $p=0.67$ ).

There was a strong correlation between severity of the disease based on physical findings (POP-Q scale) and the $\mathrm{P}$-QoL scores in main prolapse quality-of-life domains, as shown in Table 2.

The total scores for each of the P-QoL domains were found to be significantly higher for symptomatic women as compared to asymptomatic women $(p<0.001)$, as shown in Table 2.
Women with POP had significantly higher P-QoL scores indicating poorer QoL than those without prolapse. Significant differences were observed for each QoL domain between symptomatic and asymptomatic women $(p<0.001)$.

The P-QoL questionnaire demonstrated excellent internal consistency with an overall Cronbach alpha of 0.94 . In all of the seven quality of life domains the Cronbach alpha values were greater than 0.9 , demonstrating excellent internal consistency (Table 3). The internal consistency of the prolapse quality-of-life domains is shown in Table 4. 


\section{DISCUSSION}

The issue that determination of the degree of prolapse before and after the treatment alone is insufficient for the assessment of the outcome has been raised by many authors [12-14]. Decisions about the management should also be based on the quality of life of the treated women. Since the prolapse may affect different aspects of a woman's life, by limiting psychological, physical, social and sexual domains of her life, the severity of these limitations and their impact on the quality of patient life becomes an important source of information for a surgeon while deciding whether a woman needs to be treated or what kind of therapy would be the most appropriate in her case. As it was shown by Digesu et al. [2], who developed the P-QoL questionnaire, and confirmed by many authors who proved its validity [4-6], the questionnaire is a reliable instrument in a routine clinical practice and treatment follow-up. Regardless of many quality-of-life questionnaires for women suffering from urinary incontinence, there is no validated questionnaire to assess QoL of Polish-speaking women with POP. In our study, we demonstrated that the Polish version of the $\mathrm{P}-\mathrm{Q} o \mathrm{~L}$ questionnaire is a valid and reliable tool. As in other translations, we achieved excellent data consistency with Cronbach's alpha, greater than 0.9 for each domain. In our opinion, the P-QoL questionnaire currently fills the role of a quality-of-life tool in establishing the degree of severity in subjects with POP. Our results demonstrated that the P-QoL questionnaire is a practical and self-administered instrument to be used in clinical practice and research in order to assess and document the severity and impact of POP in the affected women, thus aiding clinical decisions before treatment commencement.

\section{CONCLUSIONS}

Polish version of the $\mathrm{P}-\mathrm{QOL}$ questionnaire is a validated tool for the assessment of POP in the Polish population. As in the case of the English version, the Polish version of the P-QoL questionnaire has proven to be a useful tool for assessing symptom severity of urogenital prolapse and its impact on the quality of life among the affected women. It is easy to understand and may be administrated and self-completed by the patient. Further multicenter comparison of the usefulness of this instrument would be beneficial for future reference.

\section{REFERENCES}

1. Luber KM, Boero S, Choe JY. The demographics of pelvic floor disorders: current observations and future projections. Am J Obstet Gynecol. 2001, 184: 1496-1501; discussion 1501-1503.

2. Digesu GA, KhullarV, Cardozo L, [et al.]. P-QOL: a validated questionnaire to assess the symptoms and quality of life of women with urogenital prolapse. Int Urogynecol J Pelvic Floor Dysfunct. 2005, 16 (3): 176-181; discussion 181.

3. Digesu GA, Santamato S, KhullarV, [et al.]. Validation of an Italian version of the prolapse quality of life questionnaire. Eur J Obstet Gynecol Reprod Biol. 2003, 106 (2), 184-192.

4. Lenz F, Stammer H, Brocker K, [et al.]. Validation of a German version of the P-QoL Questionnaire. Int Urogynecol J. 2009, 20 (6), 641-649.

5. Svihrova V, Digesu GA, Svihra J, [et al.]. Validation of the Slovakian version of the P-QOL questionnaire. Int Urogynecol J Pelvic Floor Dysfunct. 2010, 21, 53-61.

6. De Oliveira MS, Tamanini JTN, de Aguiar Cavalcanti G. Validation of the Prolapse Quality-of-Life Questionnaire (P-QoL) in Portuguese version in Brazilian women. Int Urogynecol J Pelvic Floor Dysfunct. 2009, 20, 1191-1202.

7. Wiwanitkit V. P-QOL questionnaire in Thai version. Int Urogynecol J. 2010, 21 (8), 1039-1039.

8. Fukumoto Y, Uesaka Y, Yamamoto K, [et al.]. (Assessment of quality of life in women with pelvic organ prolapse: conditional translation and trial of P-QOL for use in Japan). Nippon Hinyokika Gakkai Zasshi. 2008, 99 (3), 531-542.

9. Claerhout F, Moons P, Ghesquiere S, Verguts J, De Ridder D, Deprest J. Validity, reliability and responsiveness of a Dutch version of the prolapse quality-of-life (P-QoL) questionnaire. Int Urogynecol J. 2010, 21 (5), 569-578

10. Bump RC, Mattiasson A, Bø K, [et al.]. The standardization of terminology of female pelvic organ prolapse and pelvic floor dysfunction. Am J Obstet Gynecol. 1996, 175 (1), 10-17.

11. Figliola RS, Beasley DE. Theory and design for mechanical measurements. John Wiley \& Sons, New York City 1995.

12. Barber MD, Amundsen CL, Paraiso MFR, Weidner AC, Romero A, Walters $M D$. Quality of life after surgery for genital prolapse in elderly women: obliterative and reconstructive surgery. Int Urogynecol J Pelvic Floor Dysfunct. 2007, 18 (7), 799-806.

13. Digesu G, Chaliha C, Salvatore S, Hutchings A, Khullar V. The relationship of vaginal prolapse severity to symptoms and quality of life. BJOG. 2005, 112 (7), 971-976.

14. Samuelsson EC, Victor FT, Tibblin G, Svärdsudd KF. Signs of genital prolapse in a Swedish population of women 20 to 59 years of age and possible related factors. Am J Obstet Gynecol. 1999, 180, 299-305. 


\section{Wypadanie narządu rodnego \\ Jakość życia \\ (P-QoL)}

Imię i nazwisko:

Wiek: .. lat

Data:

Wypadanie narządu rodnego polega na uwypuklaniu się go do pochwy, co często powoduje dyskomfort.

PROSZĘ WYPEŁNIĆ PONIŻSZA ANKIETĘ

NAWET W PRZYPADKU NIEODCZUWANIA DOLEGLIWOŚCI ZWIAZZANYCH Z WYPADANIEM NARZADU RODNEGO!

Jak opisałaby Pani obecny stan swojego zdrowia?

(Proszę zaznaczyć jedną odpowiedź.)

Bardzo dobry

Dobry

Średni

Zły

Bardzo zły<smiles>C1=C2C=c3cc2c(c2ccccc32)=C1</smiles>

W jakim stopniu problem z wypadaniem narządu rodnego ma wpływ na Pani życie? (Proszę zaznaczyć jedną odpowiedź.)

Brak wpływu

W małym stopniu

W średnim stopniu

W dużym stopniu

Proszę zaznaczyć, jeżeli występują u Pani podane symptomy oraz podać stopień ich uciążliwości.

\begin{tabular}{|c|c|c|c|c|c|}
\hline & Nie występuje & Nieuciążliwy & $\begin{array}{l}\text { Lekko } \\
\text { uciążliwy }\end{array}$ & $\begin{array}{l}\text { Umiarkowanie } \\
\text { uciążliwy }\end{array}$ & $\begin{array}{l}\text { Bardzo } \\
\text { uciążliwy }\end{array}$ \\
\hline \multicolumn{6}{|c|}{ Częste wizyty w toalecie w celu oddania moczu } \\
\hline \multicolumn{6}{|l|}{ Nagła, bardzo silna potrzeba oddania moczu } \\
\hline \multicolumn{6}{|l|}{$\begin{array}{l}\text { Wyciekanie moczu związane z silną potrzebą } \\
\text { oddania moczu }\end{array}$} \\
\hline \multicolumn{6}{|l|}{ Wyciekanie moczu związane z kaszlem } \\
\hline \multicolumn{6}{|l|}{ Wyczuwanie wybrzuszenia w pochwie } \\
\hline \multicolumn{6}{|c|}{$\begin{array}{l}\text { Dyskomfort w pochwie, który jest większy podczas } \\
\text { stania i zmniejsza się w trakcie leżenia }\end{array}$} \\
\hline \multicolumn{6}{|l|}{ Słaby strumień moczu } \\
\hline \multicolumn{6}{|l|}{ Wysiłek przy próbie opróżnienia pęcherza } \\
\hline Kapanie moczu po opróżnieniu pęcherza & & & & & \\
\hline
\end{tabular}


Proszę zaznaczyć, jeżeli występują u Pani podane symptomy oraz podać stopień ich uciążliwości.

\begin{tabular}{|c|c|c|c|c|c|}
\hline & Nie występuje & Nieuciążliwy & $\begin{array}{l}\text { Lekko } \\
\text { uciążliwy }\end{array}$ & $\begin{array}{l}\text { Umiarkowanie } \\
\text { uciążliwy }\end{array}$ & $\begin{array}{l}\text { Bardzo } \\
\text { uciążliwy }\end{array}$ \\
\hline \multicolumn{6}{|c|}{$\begin{array}{l}\text { Uczucie nie w pełni opróżnionych jelit po } \\
\text { wypróżnieniu }\end{array}$} \\
\hline \multicolumn{6}{|l|}{ Zaparcia, trudności w wypróżnieniu } \\
\hline \multicolumn{6}{|c|}{$\begin{array}{l}\text { Wybrzuszenie w pochwie przeszkadzające we } \\
\text { współżyciu }\end{array}$} \\
\hline \multicolumn{6}{|c|}{$\begin{array}{l}\text { Ból pleców występujący razem z dyskomfortem } \\
\text { w pochwie }\end{array}$} \\
\hline
\end{tabular}

\begin{tabular}{|l|l|l|l|l|l|}
\hline & $\begin{array}{c}\text { Więcej niż raz } \\
\text { dziennie }\end{array}$ & Raz dziennie & $\begin{array}{c}\text { Raz na dwa } \\
\text { dni }\end{array}$ & $\begin{array}{c}\text { Raz na trzy } \\
\text { dni }\end{array}$ & $\begin{array}{c}\text { Raz na tydzień } \\
\text { lub rzadziej }\end{array}$ \\
\hline Jak często ma Pani wypróżnienie? & & & & \\
\hline
\end{tabular}

Poniżej znajduje się opis codziennych czynności, które mogą być zakłócone dolegliwościami związanymi z wypadaniem narządu rodnego.

W jakim stopniu owe dolegliwości wpływają na codzienne czynności u Pani?

Proszę odpowiedzieć na wszystkie pytania.

Proszę zaznaczyć odpowiednią odpowiedź.

\section{OGRANICZENIA W CODZIENNEJ AKTYWNOŚCI}

\begin{tabular}{|l|l|l|l|}
\hline & Wcale & Rzadko & Czasem \\
\hline $\begin{array}{l}\text { W jakim stopniu wypadanie narządu rodnego ogranicza Pani zajęcia } \\
\text { domowe (sprzątanie, zakupy) }\end{array}$ & & & \\
\hline $\begin{array}{l}\text { Czy wypadanie narządu rodnego wpływa na Pani pracę lub normalne } \\
\text { zajęcia poza domem w ciągu dnia? }\end{array}$ & & & \\
\hline
\end{tabular}

\section{OGRANICZENIA FIZYCZNE/SPOŁECZNE}

\begin{tabular}{|l|l|l|l|}
\hline & Wcale & Rzadko & Czasem \\
\hline $\begin{array}{l}\text { Czy wypadanie narządu rodnego ma wpływ na Pani czynności } \\
\text { fizyczne (spacer, bieganie, sport, gimnastyka, itp.) }\end{array}$ & & & \\
\hline $\begin{array}{l}\text { Czy wypadanie narządu rodnego ma wpływ na Pani zdolność } \\
\text { podróżowania? }\end{array}$ & & & \\
\hline $\begin{array}{l}\text { Czy wypadanie narządu rodnego ogranicza Pani życie towarzyskie? } \\
\text { odwy wypadanie narządu rodnego ogranicza Pani możliwości }\end{array}$ & & & \\
\hline
\end{tabular}


RELACJE OSOBISTE

\begin{tabular}{|l|l|l|l|}
\hline & Wcale & Rzadko & Czasem \\
\hline $\begin{array}{l}\text { Czy wypadanie narządu rodnego ma wpływ na Pani relacje } \\
\text { z partnerem? }\end{array}$ & & & \\
\hline Czy wypadanie narządu rodnego ma wpływ na Pani życie seksualne? & & & \\
\hline Czy wypadanie narządu rodnego ma wpływ na Pani życie rodzinne? & & & \\
\hline
\end{tabular}

EMOCJE

\begin{tabular}{|l|l|l|l|}
\hline & Wcale & Rzadko & Czasem \\
\hline Czy wypadanie narządu rodnego wywołuje u Pani przygnębienie? & & & \\
\hline $\begin{array}{l}\text { Czy wypadanie narządu rodnego powoduje, że czuje się Pani } \\
\text { nerwowa i zaniepokojona? }\end{array}$ & & & \\
\hline $\begin{array}{l}\text { Czy wypadanie narządu rodnego powoduje, że czuje się Pani } \\
\text { niepełnowartościową kobietą? }\end{array}$ & & & \\
\hline
\end{tabular}

\section{SEN/ENERGIA}

\begin{tabular}{|l|l|l|l|}
\hline & Wcale & Rzadko & Czasem \\
\hline Czy wypadanie narządu rodnego ma wpływ na Pani sen? & & & \\
\hline Czy czuje się Pani zmęczona/wykończona? & & & \\
\hline
\end{tabular}

Czy wykonuje Pani którąś z niżej opisanych czynności, aby pomóc sobie w problemie z wypadaniem narządu rodnego? Proszę podać odpowiedź nawet w przypadku, gdy uważa Pani, że nie ma problemu z wypadaniem narządu rodnego.

\begin{tabular}{|c|c|c|c|c|}
\hline & Nigdy & Czasem & Często & Cały czas \\
\hline \multicolumn{5}{|c|}{ Czy używa Pani tamponów/wkładek/ciasnej bielizny, by sobie pomóc? } \\
\hline \multicolumn{5}{|l|}{ Czy odprowadza Pani wypadający narząd rodny z powrotem? } \\
\hline Czy wypadanie narządu rodnego uniemożliwia Pani stanie? & & & & \\
\hline
\end{tabular}

Dziękujemy.

Proszę sprawdzić, czy udzieliła Pani odpowiedzi na wszystkie pytania. 